\title{
Prevalence of Protective Measures and Incident Among Motorcycle Riders with Road Safety Compliance in a Nigerian Semi-Urban Community
}

\author{
Afelumo $\mathrm{OL}^{1}$, Abiodun $\mathrm{OP}^{2}$, Sanni $\mathrm{FO}^{3}$ \\ ${ }^{1}$ Department of Healthcare Management, University of Central Nicaragua, ${ }^{2}$ Department of National Integrated \\ Specimen Referral Network, AXIOS International, Utako, FCT, Abuja, Nigeria, ${ }^{3}$ Department of Research and \\ Development, Fescosof Data Solutions, Ogun State, Nigeria
}

\section{ABSTRACT}

Introduction: The operation of commercial motorcycles has eased transport difficulties, but an increased rate of road traffic collisions, injuries, and deaths deserve attention. This study aimed to evaluate compliance with road safety preventive measures and incident prevalence among motorcycle riders in Ado-Odo Ota, Ogun State, Nigeria.

Methods: This study was a descriptive cross-sectional survey that employed a structured questionnaire for collecting information related to compliance to protective measures and incident prevalence. A stratified random sampling technique was used to identify respondents from 20 motorcycle parks. Also, a multistage probability sampling method was used to select 374 respondents from all motorcycle parks listed. Data analysis was done using IBM-SPSS version 25.0

Results: Of the 374 respondents, $69.0 \%$ owned motorcycles and $31.0 \%$ hired/rented theirs. Less than half $(45.7 \%)$ of all riders were aware of the implications (health, financial, and psychological) of a motorcycle incident. Only $39.5 \%$ of owners and $59.5 \%$ rented/hire knew the implications $(p<0.001)$. Helmet use was significantly higher among owners $(76.4 \%)$ than hired/rented $(55.2 \%), p<0.001$. More owners $(70.9 \%)$ had protective jackets than rented/hired (57.8\%) $(p<0.05)$. Availability of bright/reflective clothing was poor $(45.7 \%)$ though significantly higher among owners $(50.0 \%)$ than rented/hired $(36.2 \%)(p<0.05)$. Overall incident prevalence was $45.2 \%$, significantly higher among rented/hired riders $(56.0 \%)$ than owners $(40.3 \%)(p<0.005)$. Respondents aged $18-24$ years were more involved in MCA $(52.9 \%)$ than the other age groups $(p<0.05)$. Respondents with no formal education had more incidents $(73.1 \%)$ than the educated $(p<0.001)$.

Conclusion: The knowledge of the consequences of motorcycle incidents was limited among motorcycle riders in Ado-Odo, and the prevalence of incidents was significantly higher among riders who rented/hired motorcycles than owners. Therefore, there is a need for incident documentation and cost implication of motorcycle incidents in the local government areas; this will help policymakers design intervention programs. Also, there is a need for regular training of the riders on road safety measures and the associated benefits.

Key words: Compliance, Incident implication, Motorcycle, Prevalence, Safety measures

DOI: https://doi.org/10.3126/ijosh.v11i3.39764

Conflicts of interest: None

Supporting agencies: None

Date of submission: 29.06.2021

Date of acceptance: 02.09.2021

Date of publication: 30.09 .2021

\section{Corresponding Author}

Felix Olaniyi Sanni

Department of Research and Development

Fescosof Data Solutions

Ogun State, Nigeria

E-mail: fescosofanalysis@gmail.com

ORCID ID: https://orcid.org/0000-0001-7761-3604

\section{Introduction}

The operation of commercial motorcycles (known as Okada in Nigeria) has eased the transport difficulties encountered by the people. Thus, we can say that the Okada business has filled a significant gap in the public transport system in Nigeria. With the

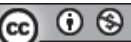

This journal is licensed under a Creative Commons AttributionNon Commercial 4.0 International License. 
operation of commercial motorcycles, people can now go to areas previously impregnable by conventional means of transportation. For example, there were some rural suburbs that conventional commercial buses and taxis could not reach. The Okada has now provided a means of transportation for commuters in these areas. In Ado Odo-Ota local government area (LGA) in Ogun State, the interior Sango, llogbo, Ojuore, Atan, and many more have been opened up by Okada.

However, the motorcyclist spends more than 10 hours on the road and is directly exposed to numerous environmental hazards, including road traffic incidents and related crash incidents of varying severity levels. ${ }^{1}$ There was also an increase in the rate of road traffic collisions associated with commercial motorcycling, increasing the number of hospital injuries. ${ }^{2,3}$ In addition, the incidents are correlated with tremendous socioeconomic effects for the victims, their families, and society. ${ }^{4,5}$

Many explanations for the unacceptably high rate of road traffic incidents involving commercial motorcycle riders have been proposed. The causes vary from human factors and conditions for vehicles to roads in Nigeria. ${ }^{1,6}$ The risk of death among motorcycle riders is twenty times higher than among car occupants. ${ }^{7}$ About two-thirds of all road traffic incidents in Nigeria involve commercial motorcycle riders. ${ }^{1} \mathrm{~A}$ large proportion of the deaths in Ogun state are also due to commercial motorcycle crashes. ${ }^{1} \mathrm{~A}$ significant risk factor for incidents among commercial motorcycle riders is excessive speed resulting from impatience to make higher returns. ${ }^{8,9}$ For other road users, other causes include poorly maintained motorcycles, poor roads, and lack of knowledge of basic traffic regulations and the consequences of road traffic incidents. ${ }^{9}$ Significant risk factors for incidents among commercial motorcyclists have also been unhealthy social activities indulged in by motorcyclists. The use of alcohol, cigarette smoking, and the misuse of psychoactive drugs affect drivers' judgment and ability to perceive incidents correctly. ${ }^{10-12}$ However, the use of protective measures has been shown to substantially reduce the severity of injuries that can result from road traffic incidents. ${ }^{10,13}$ Studies have shown a high prevalence of risk actions among commercial motorcyclists involved in road traffic incidents and severe crash injuries due to a lack of safety knowledge, compliance with these measures, and non-enforcement of laws banning highrisk behaviors. ${ }^{1}$
One big way to minimize motorcycle morbidity and mortality is by using safety devices and observing precautionary safety measures. ${ }^{14}$ According to the WHO (2020), correct helmet use can reduce the risk of fatal injuries to $42 \%$ and head injuries to $69 \% .{ }^{4}$ It can also reduce the duration of stay in the hospital and medical bills for injured riders ${ }^{4}$. A motorcyclist without a helmet has a $40 \%$ greater chance of fatal head injury and a $15 \%$ more chance of non-fatal injury than a rider with a helmet when they have a crash. ${ }^{15}$ Besides, the rates and patterns of use under national regulation can differ significantly depending on education, penalty charging, and compliance. ${ }^{16}$ The rules for using motorcycles for passenger transport in Nigeria are laid down in the 2004 National Road Traffic Regulations (Federal Republic of Nigeria), which require, among other items, the use of helmets for riders and pillion. ${ }^{17}$ Despite these rules and responsibilities, motorcycle riders' usage of protective devices in Nigeria remained poor. In an investigation into the know-how, behavior, and practice of business motorcyclists in lle Ife, South West of Nigeria, $20 \%$ of motorists suggested using a crash cask as one safety device, and $23,8 \%$ suggested wearing a helmet at the time of the report. ${ }^{18}$

Some personal protection aids readily available to commercial motorcyclists are helmets, goggles, and gloves, yet only a few commercial motorcycle riders use these devices. It should be remembered that deaths and injuries from road traffic can be prevented. However, the only secret to effective prevention lies in determining all relevant stakeholders representing different sectors: public and private health, transport, education, finance, police, politicians, suppliers, foundations, and the media. This study evaluates the riders' knowledge of the implications of road traffic incidents and compliance with road safety and preventive measures in Ado-Odo Ota LGA of Ogun State, South-West, Nigeria. Due to inadequate local data, motorcycle incidents have not received the attention they deserve in this state, and public policy solutions to this crisis have been ignored. So, it is necessary to determine the riders' knowledge and compliance with road safety and preventive measures and their association with incident prevalence.

\section{Methods}

A descriptive cross-sectional survey conducted in Ogun State, Nigeria, in Ado Odo Ota local government area. The sample population was based on the number 
of registered motorcycles (620)in the LGA indicate in "digest of motor vehicle statistics," 2017 edition. ${ }^{19}$ This number was used because there is no recent data on the number of registered motorcycles in the LGA, meaning that there may be more riders in the LGA than 620.

The sample size was estimated using the formula $\mathrm{n}=\frac{Z^{2} \mathrm{p} \mathrm{q}}{d^{2}}$

Where: $\mathrm{n}$ is the sample size, $\mathrm{Z}=1.96$ for $95 \%$ Confidence level. $\mathrm{P}$ is the prevalence of road safety and preventive measures among Nigerian motorcycle riders $(67 \%=0.67)^{20}$, and $q=1-p(1-0.67=0.33), d$ is marginal error $=0.05$.

The estimated sample was 340 and 374 with $10 \%$ allowable attrition.

A multistage probability sampling method was used to select 374 respondents from all motorcycle parks listed. There were 20 motorcycle parks identified through stratified random sampling from five major divisions. A simple random sample selection was used to select 19 participants from fifteen bigger parks and 18 participants from the remaining five smaller parks. Data collection was done from January 25 to February 30, 2021. The information obtained from the respondents includes the sociodemographic data, knowledge of the implications of motorcycle incidents, availability, and compliance with safety measures, as well as incident prevalence.

Data analysis was done using IBM-Statistical Package for Social Sciences (IBM-SPSS) version 25.0 for Windows IBM Corp., Armonk, NY, USA. Association between dependent variables (knowledge of implications of MCA, compliance with safety measures, and motorcycle incidents) and independent variables (ownership, age category, marital status, education, and year of experience) was determined using Chisquare statistics and $p$-value $<0.05$ was considered significant.

Motorcycle riders included in this study must be 18 years old and above, below 60 years, riding a motorcycle in the LGA for at least one year, and must be full-time riders. At the same time, those that did not satisfy inclusion criteria were excluded.

Approval for the study was taken from the National Health Research Ethics Committee of Nigeria (NHREC) with approval number HREC/01/01/2007-
20/01/2021. Data collected from respondents were treated confidentially, and no traceable information to any of them was collected. All respondents were informed of the study protocol, and both verbal and written consent was obtained before questionnaires were administered to them.

The knowledge of the implications of motorcycle incidents was assessed with eight questions, including "reduction of working capacity," "physical disabilities," "burden of the cost of medication," "loss of livelihood," "loss of parents and family loved ones," "intangible costs (i.e., pain, grief, and suffering)," "medical costs, funeral costs, and property damage," "psychological distress, i.e., posttraumatic stress disorder and major depressive disorder." An overall score of at least 70\% was considered high knowledge, while scores lower than $70 \%$ were termed insufficient knowledge ${ }^{21}$.

\section{Results}

As shown in Table 1, most motorcycle riders (69.0\%) own the motorcycles, while $31.0 \%$ either hired it in instalments or rented for daily delivery of specific amounts. The highest proportion of these riders was between $25-44$ years, with the peak age of $35-$ $44(38.0 \%)$, and the majority were married $(86.9 \%)$. More than half $(53.7 \%)$ had secondary education, had children $(90.6 \%)$, and have been doing commercial riding work for seven or more years $(49.7 \%)$.

The respondents were classified into two groups; group one is those that hired/rented motorcycles for business, and group two are the riders that own the motorcycles. Of the 374 respondents, $69.0 \%$ owned motorcycles and $31.0 \%$ hired/rented theirs. Most of them were married $(86.9 \%)$ and $(38.0 \%)$ were within $35-44$ years, had secondary education (53.7\%), had children (90.6\%), and have been doing riding business for more than six years $(49.7 \%)$ (Table 1 ).

Respondents' mean scores out of five from eight questions used to evaluate their knowledge about the implications of MCA are shown in Table 2. Both groups were similarly aware that MCA might lead to the reduced working capacity of its victims (owned3.25 , rented/hired-3.48) ( $p>0.05)$. Those that rented/ hired motorcycles were significantly more aware that MCA could result in a burden of the costs of medication (3.61), cause pain, grief, and suffering (3.65), cause medical costs, funeral costs, and property damage (3.66), and could cause psychological distress 
(posttraumatic stress disorder and major depressive disorder) (3.28) than motorcycle owners $(p<0.05)$.

Table 3 displays the knowledge of motorcycle riders about the implications of motorcycle incidents. From the eight questions on the impacts of MCA, less than half $(45.7 \%)$ of all riders displayed good knowledge, and $54.3 \%$ had insufficient knowledge. Thus, only $39.5 \%$ of motorcycle owners knew the implications of MCA incidents whereas, about three-fifths (59.5\%) of rented/hired ones had good knowledge $(p<0.001)$. On the other hand, more than half of riders aged 18 -24 (52.9\%) and $45-54(62.4 \%)$ displayed adequate knowledge than others $(p<005)$. Similarly, riders with secondary education $(53.7 \%)$ and those that have been riding for more than six years $(59.7 \%)$ showed better knowledge of the implications of MCA than the rest $(p<0.001)$.

The proportion of riders wearing helmets at the time of the interview was (69.8\%) but higher (76.4\%) among motorcycles owners than hired/rented (55.2\%), $p<0.001$. The majority $(90.1 \%)$ had a functional headlamp though no significant difference was between owners (88.8\%) and hired/rented (93.1\%) ( $p>0.05)$. More owners $(70.9 \%)$ had protective jackets than rented/hired $(57.8 \%)(p<0.05)$. Availability of functional speedometer was not significantly different between owners $(76.4 \%)$ and hired/rented $(83.6 \%)$ ( $p>0.05)$. There was an overall poor availability of bright/ reflective clothing $(45.7 \%)$ though significantly higher among owners $(50.0 \%)$ than rented/hired $(36.2 \%)$ $(p<0.05)$. Availability of connecting gloves $(41.2 \%)$ and a pair of the boot $(38.8 \%)$ were generally poor and not significantly different between both groups ( $p>0.05)$.

The majority of the riders had two functioning indicators (79.9\%) but significantly higher (85.3\%) among hired/ rented bikes than owners $(77.5 \%)(p<0.001)$. On the other hand, the overall availability of wing mirrors was $(57.8 \%)$ with $56.9 \%$ among rented/hired motorcycles and $58.1 \%$ among owners ( $p>0.05$ ), as shown in Table 4.

Incident prevalence within 12 months was $45.2 \%$, significantly higher among rented/hired riders (56.0\%) than owners $(40.3 \%)(p<0.005)$. Most of the incidents occurred during the day $(82.2 \%)$ and mainly on the highways $(70.4 \%)$ ( $p>0.05)$. More than half $(56.4 \%)$ were hit by another vehicle from behind. Also, 77.8\% knew somebody who has been involved in a motorcycle incident in the previous 12 months, as shown in Table 4.

Table 5 shows the demographic distribution of respondents that have had an incident or more in the previous 12 months. Respondents aged 18-24 years were more involved in MCA $(52.9 \%)$ than the other age groups $(p<0.05)$. Divorced/widowed respondents had more incidents $(47.6 \%)$ than married $(45.5 \%)$ and singles $(39.3 \%)(p>0.05)$. Respondents with no formal education had more incidents $(73.1 \%)$, and respondents with tertiary education were the least $(25.4 \%)(p<0.001)$. More than half of those that have been doing riding business for 4-6 years had had incidents $(51.2 \%)$ than the rest $(p<0.05)$.

Table 1: Sociodemographic characteristics of the respondents

\begin{tabular}{llcc}
\hline Parameter & Response & Frequency $\mathbf{( n = 3 7 4 )}$ & Percentage \\
\hline \multirow{2}{*}{ Ownership } & Rented/Hired & 116 & 31.0 \\
& Owned & 258 & 69.0 \\
& $18-24$ & 17 & 4.5 \\
Age category (years) & $25-34$ & 124 & 33.2 \\
& $35-44$ & 142 & 38.0 \\
& $45-54$ & 91 & 24.3 \\
Marital status & Single & 28 & 7.5 \\
& Married & 325 & 86.9 \\
& Divorced/separated/widowed & 21 & 5.6 \\
Level of education & No formal education & 26 & 7.0 \\
& Primary & 88 & 23.5 \\
& Secondary & 201 & 53.7 \\
Have children & Tertiary & 59 & 15.8 \\
Yes & No & 339 & 90.6 \\
Yiding & $1-3$ years & 35 & 9.4 \\
\hline
\end{tabular}


Table 2: Means score of knowledge of the motorcycle riders about the implications of motorcycle incidents

\begin{tabular}{|c|c|c|c|c|}
\hline Implication & Rented/Hired n(\%) & Owned n(\%) & Overall n(\%) & P-value \\
\hline Reduction of working capacity & $3.25(65.0)$ & $3.48(69.6)$ & $3.41(68.2)$ & 0.206 \\
\hline Physical disabilities & $3.17(63.4)$ & $2.85(57)$ & $2.95(59)$ & 0.082 \\
\hline Burden of cost of medication & $3.61(72.2)$ & $3.18(63.6)$ & $3.32(66.4)$ & $0.016^{*}$ \\
\hline Loss of livelihood & $2.81(56.2)$ & $2.76(55.2)$ & $2.77(55.4)$ & 0.760 \\
\hline Loss of parents and livelihood & $2.79(55.8)$ & $2.62(52.4)$ & $2.68(53.6)$ & 0.306 \\
\hline $\begin{array}{l}\text { Intangible costs (i.e., pain, grief and } \\
\text { suffering) }\end{array}$ & $3.65(73)$ & $3.11(62.2)$ & $3.28(65.6)$ & $0.001^{*}$ \\
\hline $\begin{array}{l}\text { Medical costs, funeral costs, and } \\
\text { property damage }\end{array}$ & $3.66(73.2)$ & $3.2(64)$ & $3.34(66.8)$ & $0.008^{*}$ \\
\hline $\begin{array}{l}\text { Psychological distress i.e., } \\
\text { posttraumatic stress disorder and } \\
\text { major depressive disorder }\end{array}$ & $3.28(65.6)$ & $2.93(58.6)$ & $3.04(60.8)$ & $0.046^{*}$ \\
\hline
\end{tabular}

*-significant at $p<0.05$ level; figures shown in bracket are in percentage

Table 3: Sociodemographic distribution of the knowledge of the implications of motorcycle incidents

\begin{tabular}{|c|c|c|c|c|c|}
\hline \multirow{2}{*}{ Parameters } & \multirow{2}{*}{ Response } & \multicolumn{3}{|c|}{ Knowledge of implications of MCA } & \multirow[b]{2}{*}{ P-value } \\
\hline & & Poor $n(\%)$ & Good $n(\%)$ & Total $n(\%)$ & \\
\hline \multirow{2}{*}{ Ownership } & Rented/Hired & $47(40.5)$ & $69(59.5)$ & $116(31.0)$ & \multirow{2}{*}{$<0.001^{*}$} \\
\hline & Owned & $156(60.5)$ & $102(39.5)$ & $258(69.0)$ & \\
\hline \multirow{4}{*}{ Age category } & $18-24$ & $8(47.1)$ & $9(52.9)$ & $17(4.5)$ & \multirow{4}{*}{$0.028^{*}$} \\
\hline & $25-34$ & $79(63.7)$ & $45(36.3)$ & $124(33.2)$ & \\
\hline & $35-44$ & $82(57.7)$ & $60(42.3)$ & $142(38.0)$ & \\
\hline & $45-54$ & $34(37.4)$ & $57(62.6)$ & $91(24.3)$ & \\
\hline \multirow{3}{*}{ Marital status } & Married & $162(49.8)$ & $163(50.2)$ & $325(86.9)$ & \multirow{3}{*}{$<0.001^{*}$} \\
\hline & Single & $22(78.6)$ & $6(21.4)$ & $28(7.5)$ & \\
\hline & $\begin{array}{l}\text { Divorced/separated/ } \\
\text { widowed }\end{array}$ & $19(90.5)$ & $2(9.5)$ & $21(5.6)$ & \\
\hline \multirow{4}{*}{ Education } & No formal education & $17(65.4)$ & $9(34.6)$ & $26(7.0)$ & \multirow{4}{*}{$0.001^{*}$} \\
\hline & Primary & $55(62.5)$ & $33(37.5)$ & $88(23.5)$ & \\
\hline & Secondary & $90(44.8)$ & $111(55.2)$ & $201(53.7)$ & \\
\hline & Tertiary & $41(69.5)$ & $18(30.5)$ & $59(15.8)$ & \\
\hline \multirow{2}{*}{ Have children } & Yes & $182(53.7)$ & 157 (46.3) & $339(90.6)$ & \multirow{2}{*}{0.475} \\
\hline & No & $21(60.0)$ & $14(40.0)$ & $35(9.4)$ & \\
\hline \multirow{4}{*}{ Year of experience } & 1 - 3 years & $38(60.3)$ & $25(39.7)$ & $63(16.8)$ & \multirow{3}{*}{$<0.001^{*}$} \\
\hline & 4 - 6 years & $90(72.0)$ & $35(28.0)$ & 125 (33.4) & \\
\hline & Above 6 years & $75(40.3)$ & $111(59.7)$ & 186 (49.7) & \\
\hline & Total & $203(54.3)$ & $171(45.7)$ & $374(100.0)$ & \\
\hline
\end{tabular}

*-significant at $p<0.05$ level; figures shown in bracket are in percentage

Table 4: Level of Compliance with the use of safety devices/road safety and preventive measures

\begin{tabular}{|c|c|c|c|c|c|}
\hline SN & & $\begin{array}{c}\text { Rented/Hired } \\
n(\%) n=116\end{array}$ & $\begin{array}{c}\text { Owned } n(\%) \\
n=258\end{array}$ & $\begin{array}{c}\text { Total } n(\%) \\
n=374\end{array}$ & P-value \\
\hline 1 & Have helmet & $64(55.2)$ & $197(76.4)$ & $261(69.8)$ & $<0.001^{*}$ \\
\hline 2 & Have functional headlights present & $108(93.1)$ & $229(88.8)$ & $337(90.1)$ & 0.193 \\
\hline 3 & Have protective jacket & $67(57.8)$ & $183(70.9)$ & $250(66.8)$ & $0.012^{*}$ \\
\hline 4 & Functional speedometer present & $97(83.6)$ & $197(76.4)$ & $294(78.6)$ & 0.113 \\
\hline 5 & Bright /reflective clothing available & $42(36.2)$ & $129(50.0)$ & $171(45.7)$ & $0.013^{*}$ \\
\hline 6 & Connecting gloves present & $45(38.8)$ & $109(42.2)$ & $154(41.2)$ & 0.530 \\
\hline 7 & A pair of boot present & $46(39.7)$ & $99(38.4)$ & $145(38.8)$ & 0.814 \\
\hline
\end{tabular}




\begin{tabular}{|c|c|c|c|c|c|}
\hline \multirow{4}{*}{8} & Number of direction indicators present & & & & \multirow{4}{*}{$<0.001^{*}$} \\
\hline & Not available & $17(14.7)$ & $23(8.9)$ & $40(10.7)$ & \\
\hline & One & $0(0.0)$ & $35(13.6)$ & $35(9.4)$ & \\
\hline & Two & $99(85.3)$ & $200(77.5)$ & $299(79.9)$ & \\
\hline \multirow{4}{*}{9} & Number of wing mirrors present & & & & \multirow{4}{*}{0.630} \\
\hline & Not available & $40(34.5)$ & $79(30.6)$ & $119(31.8)$ & \\
\hline & One & $10(8.6)$ & $29(11.2)$ & $39(10.4)$ & \\
\hline & Two & $66(56.9)$ & $150(58.1)$ & $216(57.8)$ & \\
\hline
\end{tabular}

*-significant at $p<0.05$ level; figures shown in bracket are in percentage

Table 4: Prevalence of motorcycle road incidents among the respondents within the last 12 months

\begin{tabular}{|c|c|c|c|c|c|}
\hline SN & Incidents & $\begin{array}{c}\text { Rented/ } \\
\text { Hired } n=116\end{array}$ & $\begin{array}{l}\text { Owned } \\
n=258\end{array}$ & $\begin{array}{c}\text { Total } \\
n=374\end{array}$ & P-value \\
\hline 1 & $\begin{array}{l}\text { Had an incident that resulted in injury in the } \\
\text { previous } 12 \text { months }\end{array}$ & $65(56.0)$ & $104(40.3)$ & $169(45.2)$ & $0.005^{*}$ \\
\hline \multirow{3}{*}{2} & Number of Incidents & & & & \multirow{3}{*}{$0.008^{*}$} \\
\hline & $1-2$ incidents & $59(90.8)$ & $77(74.0)$ & $136(80.5)$ & \\
\hline & 3 or more & $6(9.2)$ & $27(26.0)$ & $33(19.5)$ & \\
\hline \multirow{3}{*}{3} & Period of incident & & & & \multirow{3}{*}{0.849} \\
\hline & During the day & $53(81.5)$ & $86(82.7)$ & $139(82.2)$ & \\
\hline & In the night & $12(18.5)$ & $18(17.3)$ & $30(17.8)$ & \\
\hline \multirow{3}{*}{4} & Place of incident & & & & \multirow{3}{*}{0.143} \\
\hline & Highway & $50(76.9)$ & $69(66.3)$ & $119(70.4)$ & \\
\hline & Streets & $15(23.1)$ & $35(33.7)$ & $50(29.6)$ & \\
\hline \multirow{7}{*}{5} & Frequency of collision with other vehicles & & & & \\
\hline & Collisions while overtaking other road users & $36(31.0)$ & $100(38.8)$ & $136(36.4)$ & 0.151 \\
\hline & $\begin{array}{l}\text { Being hit from behind by other road users (rear- } \\
\text { end shunt) }\end{array}$ & $60(51.7)$ & $151(58.5)$ & $211(56.4)$ & 0.220 \\
\hline & Collisions with right-turning vehicles & $36(31.0)$ & $101(39.1)$ & $137(36.6)$ & 0.132 \\
\hline & Collisions with left-turning vehicles & $41(35.3)$ & $77(29.8)$ & $118(31.6)$ & 0.290 \\
\hline & $\begin{array}{l}\text { Poor riding technique leading to loss of control of } \\
\text { the motorcycle }\end{array}$ & $15(12.9)$ & $33(12.8)$ & $48(12.8)$ & 0.970 \\
\hline & Over-shooting bends in the road & $12(10.3)$ & $36(14.0)$ & $48(12.8)$ & 0.334 \\
\hline 6 & $\begin{array}{l}\text { Knows somebody who has been involved in an } \\
\text { incident in the last } 12 \text { months }\end{array}$ & $84(72.4)$ & $207(80.2)$ & $291(77.8)$ & 0.092 \\
\hline
\end{tabular}

*-significant at $p<0.05$ level; figures shown in bracket are in percentage

Table 5: Demographic distribution of MCA among riders in the previous 12 months

\begin{tabular}{lccccc}
\hline \multirow{2}{*}{ Parameters } & \multirow{2}{*}{ Response } & \multicolumn{4}{c}{ Involved in an incident in the previous 12 months } \\
\cline { 2 - 5 } & 18 Yes $(\mathbf{n}=169)$ & No $(\mathbf{n}=\mathbf{2 0 5})$ & $\mathbf{X}^{2}$ & P-value \\
\hline \multirow{3}{*}{ Age category } & 18 24 & $9(52.9)$ & $8(47.1)$ & & \\
& $25 \sim 34$ & $56(45.2)$ & $68(54.8)$ & 8.288 & $0.040^{*}$ \\
& $35 \sim 44$ & $53(37.3)$ & $89(62.7)$ & & \\
Marital status & $45 \sim 54$ & $51(45.2)$ & $40(44.0)$ & & \\
& Married & $148(45.5)$ & $177(54.5)$ & & \\
& Single & $11(39.3)$ & $17(60.7)$ & 0.46 & 0.795 \\
& Divorced/separated/widowed & $10(47.6)$ & $11(52.4)$ & &
\end{tabular}




\begin{tabular}{|c|c|c|c|c|c|}
\hline \multirow{4}{*}{ Education } & No formal education & 19 (73.1) & $7(26.9)$ & \multirow{4}{*}{18.034} & \multirow{4}{*}{$<0.001^{*}$} \\
\hline & Primary & $39(44.3)$ & $49(55.7)$ & & \\
\hline & Secondary & $96(47.8)$ & $105(52.2)$ & & \\
\hline & Tertiary & $15(25.4)$ & $44(74.6)$ & & \\
\hline \multirow{2}{*}{ Have children } & Yes & $151(44.5)$ & $188(55.5)$ & \multirow{2}{*}{0.607} & \multirow{2}{*}{0.436} \\
\hline & No & $18(51.4)$ & $17(48.6)$ & & \\
\hline \multirow{3}{*}{ Year of experience } & 1 - 3 years & $19(30.2)$ & $44(69.8)$ & \multirow{3}{*}{7.652} & \multirow{3}{*}{$0.022^{*}$} \\
\hline & 4 - 6 years & $64(51.2)$ & $61(48.8)$ & & \\
\hline & Above 6 years & $86(46.2)$ & $100(53.8)$ & & \\
\hline \multirow{3}{*}{$\begin{array}{l}\text { Knowledge of } \\
\text { implication of incident }\end{array}$} & Poor & $90(44.3)$ & $113(55.7)$ & \multirow{2}{*}{0.13} & \multirow{2}{*}{0.718} \\
\hline & Good & $79(46.2)$ & $92(53.8)$ & & \\
\hline & Total & $157(42.0)$ & $103(27.5)$ & $114(30.5)$ & \\
\hline
\end{tabular}

*-significant at $p<0.05$ level; figures shown in bracket are in percentage

\section{Discussion}

The respondents showed overall insufficient knowledge of the implications or consequences of motorcycle incidents. This inadequate knowledge might be responsible for high incident prevalence in the local government, emphasizing the need for regular awareness programs and training for all riders. However, older and married riders displayed better knowledge of the consequences of motorcycle incidents than younger ones, which might be due to the long-time experiences they had in the business. Studies have proposed that understanding the effects of $\mathrm{MCl}$ may significantly reduce incident rates and suggested regular training for road users. ${ }^{22-25}$ However, this finding also underlines the need for accurate assessment of MCl's implication (both costs and noncost) in this area to help design interventions towards reducing motorcycle incidents in the environment and the entire state.

There was a suboptimal level of helmet use among all respondents $(69.8 \%)$ but slightly higher than half among riders who hired motorcycles (55.2\%) as compared to over $70 \%$ of those who owned the motorcycles $(p<0.001)$. This value is higher than an estimated helmet usage of $20 \%$ among motorcycle riders in Nigeria by the Federal Road Safety Corps. ${ }^{9}$ Studies have shown that the use of helmets significantly reduces motorcycle fatality. ${ }^{26}$ Similar to the findings of this study, a study conducted in Ilorin, Kwara State, Nigeria, found poor compliance with road safety and preventive measures and helmet usage. ${ }^{27}$ Several other studies have reported low helmet usage among motorcycle riders in Nigeria, including $12.8 \%$ reported and $0.7 \%$ observed usage in Abuja, ${ }^{28} 77 \%$ never used helmet before in $\mathrm{Ibadan}^{29}$ and $4.3 \%$ usage among riders in Oshogbo, Southwest Nigeria, ${ }^{14}$ Although this study did not assess the reasons for the non-usage of the helmet, the reasons may not be different from other studies that reported non-availability, lack of enforcement, and discomfort as significant reasons for non-usage of helmet among motorcycle riders and pillion passengers. ${ }^{28,29}$ Poor riders' helmet usage is not limited to Nigeria as lower usage than the finding of this study has been reported in other African countries. In Tanzania, the non-consistent use of helmets among motorcycle riders was reported as $67.6 \%,{ }^{30}$ while only $1.9 \%$ wear crash helmets in a study conducted in Egypt, ${ }^{5}$ only $4 \%$ wore a helmet in Kenya, ${ }^{31}$ and $43.6 \%$ in Ghana. ${ }^{10}$

A very high proportion of both groups had functional headlamps, speedometers, and two functioning indicators, but a higher proportion of hired motorcycles had than the owned ones. This attitude may be because most hired motorcycles were new (mainly rented in installments), whereas owners ride old ones. On the other hand, there was a higher availability of protective jackets among motorcycle owners than the hired ones. However, there was low availability of bright/reflective clothing, connecting gloves, and wing mirrors in both groups of motorcycle riders. Although protective wear has been recommended and made mandatory for motorcycle riders in Nigeria, ${ }^{9}$ studies have reported variations in the use of protective jackets and other clothing by riders; while some wear jackets, they may not wear protective trousers consistently. ${ }^{32-34}$ For example, a study conducted in Makurdi, Benue State, Nigeria, reported low wing mirrors availability $(2 \%)$ among motorcycle riders. ${ }^{25}$ 
Similarly, a study conducted on 363 motorcycle incident patients (including riders, passengers, and pedestrians) found that none of them was wearing protective/ reflective clothing at the time of the incidents. ${ }^{35}$ The $66.8 \%$ availability of protective/reflective wear in this study can be attributed to improved awareness over the last decade. However, the finding of some studies outside Nigeria reported lower availability/usage of protective wears among riders. Studies from Nairobi and Kisumu, Kenya, found that $45.5 \%{ }^{4}$ and $45.9 \%{ }^{36}$ used protective/reflective wear. Whereas another study carried out in 11 cities in same Kenya, found 16\% use. Also, a survey conducted among 424 respondents in the USA and Canada found that $39.8 \%$ of the respondents stated that they always use protective clothing and $20.6 \%$ almost always. ${ }^{37}$ These findings underscore the need for consistent enforcement of the Nigerian highway code in Ota and Nigeria.

There was an unacceptably high rate of incidents $(45.2 \%)$ among all the riders in ado-Odo Ota, in Ogun State, in the last 12 months. This prevalence is slightly lower than $54.8 \%$ previously reported in this LGA in $2017 .^{38}$ The difference may be because this study assessed 12 months of incident history, whereas Kolawole and Afolabi assessed incident history since the respondents started riding motorcycles. This study found that the prevalence of incident in the last 12 months was significantly higher $(p<0.05)$ among the respondent who was driving hired/rented motorcycles $(56.0 \%)$ than those who were using owned motorcycles $(40.3 \%)$, indicating a difference of $15.7 \%$. Besides, most incidents occurred during the day and on the highways among hired/rented motorcycles $(80 \%)$. This finding justifies the ban placed on motorcycles on highways in some cities in Nigeria. ${ }^{1,9,22,39-42}$ It is necessary to replicate such in Ado-Odo Ota LGA since it borders Lagos and is densely populated.

Like the high motorcycle incident prevalence of $45.2 \%$ found in this study, a study conducted in Ibadan, Oyo State, reported a $45.3 \%$ incident prevalence. ${ }^{43}$ However, a higher prevalence $(74.0 \%)$ in the last 12 months than $45.2 \%$ found in this study was reported among motorcycle riders in Ghana. ${ }^{10}$ Still, slightly lower was found in some other regions, such as $37.8 \%$ in Mwea Town in Kenya ${ }^{44} 44.7 \%$ in Nairobi Kenya, ${ }^{4}$ and $40.3 \%$ in Kisumu county, Kenya. ${ }^{36}$

The higher rate of incidents among rented motorcycle riders might be because they had to deliver a certain amount to the owner each day or pay monthly installments. Also, the anxiety to meet daily personal and family needs may cause them to avoid necessary safety rules and measures and often end up in road crashes, unlike riders who owned the motorcycles with less pressure. Previous studies have reported similar findings that high risk and incidents among motorcycle riders are due to the need to earn sufficient money to meet daily needs, pay rents, ticket fees, and installment payments to the motorcycle owner. ${ }^{45,46}$

Also, regular stoppage by law enforcement agents, who forcefully extort them, even without committing any road offense and high-ticket fee, might have contributed to the high rate of incidents in the LGA. Another factor is the poor road conditions and lack of parking space which may psychologically affect the riders and consequently result in incidents, particularly when riders have to remain in Sun or rain due to lack of proper parking space. Since these figures are self-reported, there is the possibility that they were underreported, especially those who ride rented motorcycles. Bad roads in Nigeria have been consistent over several decades and have been constantly reported as a challenge and a significant cause of road incidents in Nigeria. ${ }^{35,38,47}$

The major limitation of this study is that the prevalence of motorcycle incidents was estimated based on selfreported information, which may be generally reliable. However, the study's strength is that the findings represent motorcycle riders in Ado-Odo Ota LGA since the survey was conducted across the local government areas. Also, the study shows apparent differences between hired/rented riders and those who owned motorcycles.

\section{Conclusion}

The knowledge of the consequences of motorcycle incidents was limited among motorcycle riders in AdoOdo Ota LGA, and the prevalence of incidents was significantly higher among riders who rented/hired motorcycles than owners. Therefore, there is a need for incident documentation and cost implication of motorcycle incidents in the LGA to help policymakers design intervention programs. Furthermore, since the study found a higher prevalence of incidents among riders who rented/hired motorcycles, it is recommended that the government subsidizes motorcycles and spreads the payment over a long period to reduce anxiety and reduce incident rates. 


\section{References}

1. Salako A, Abiodun O, Sholeye O. Risk behaviors for road traffic incidents and severe crash injuries among commercial motorcyclists in Sagamu, South West, Nigeria. 2013; 2: 19-23.

2. Onyemaechi N. Road traffic injuries in a Nigerian referral trauma center: Characteristics, correlates, and outcomes. Int J Crit IIIn Inj Sci.2020; 10: 64-9.

3. Yange TS, Onyekwere $O$, Rufai MA, et al. Determination of the Severity of Motorcycle and Tricycle Incidents in Nigeria. Adv Appl Sci 2020; 5: 41-8.

4. Hawa SM. Incidences And Implications Of Road Traffic Incidents Among Commercial Motorcyclists In Embakasi Area, Nairobi County. Egerton University, (2019). Available from : http://dx.doi. org/10.1101/843326 (2019).

5. Bolbol SA, Zalat \& MM. Motorcycle Riders' Risky Behaviors and Safety Measures: a Hospital-Based Study. Egypt J Occup Med. 2018; 42: 453-68.

6. Babafemi AA, Ikiomoye BL, Data AB. Road Safety Behaviour of Motor-Cyclists and their Passengers in Obafemi Awolowo University Ile-Ife, Nigeria. Glob Environ Health Saf. 2019; 3: 1.

7. Centers for Disease Control and Prevention (CDC). Road Traffic Injuries \& Deaths: A Global Problem | CDC. 2020; 1-5.

8. Farah BS. The Economic Cost And Policy Implications Of Heavy Goods Vehicles Road Traffic Incidents In Nigeria. University of Huddersfield. 2016: 1-279 Available from : http://eprints.hud.ac.uk/ id/eprint/34524/

9. International Transport Forum (ITF). Road Safety Annual Report 2018 The Netherlands. Nigeria, 2018.

10. Konlan KD, Doat AR, Mohammed I, et al. Prevalence and Pattern of Road Traffic Incidents among Commercial Motorcyclists in the Central Tongu District, Ghana. Sci World J; 2020. Available from : https://www.hindawi.com/journals/ tswj/2020/9493718/

11. Ogunmodede T, Akangbe C. Effect of road safety information availability and utilization on commercial motorcycle incidents in Nigeria. Int J Lib Info 2013; 5: 68-76.

12. Osinowo OA, Amaefula ET, Island W, et al. RiskTaking Behaviour among Commercial Motorcycle Taxi [Okada] Riders in a Semi-Rural Area of Bayelsa State. Int J Heal Sci Res; 7 (4): 68-76.

13. Oginni FO, Ugboko VI, Adewole RA. Knowledge, attitude, and practice of Nigerian commercial motorcyclists in the use of crash helmet and other safety measures. Traffic Inj Prev 2007; 8(2): 137-41.
14. Olakulehin O. Helmet use among motorcycle riders Insemi-Urban communities in Southwestern Nigeria. Int Res J Med Med Sci 2015; 06: 35-9.

15. National Highway Traffic Safety Administration (NHTSA). Traffic Safety Facts: Motorcycle Helmet Use in 2008. 2009. United States Department of transport. Washington. United States of America

16. Global Status Report On Road Safety. 2008. World Health Organization (WHO), Geneva, Swizerland. Available from : https://www.uam.es/ gruposinv/meva/publicaciones jesus/capitulos_ espanyol_jesus/2005_motivacion para el aprendizaje Perspectiva alumnos.pdf\%0Ahttps:// www.researchgate.net/profile/Juan_Aparicio7/ publication/253571379_Los_estudios_sobre_el_ cambio_conceptual_(2019).

17. National road regulations. Lagos. Federal government press. 2004. Republic of Nigeria (FRN).2005. Available from : https://gazettes.africa/ archive/ng/2005/ng-government-gazette-dated2005-12-30-no-115.pdf

18. Ngari PM. Incidence and Correlates of Commercial Motorcycle Incidents in Embu Town, Kenya. Texila Int J Public Heal 2019; 7(1): 122-30.

19. Death Statistical Master Files (DSMF). Digest of Motor Vehicle Statistics 2017 Edition. 2017: 1-34. Available from : https://www.gov.bm/sites/ default/files/2019-Digest-of-Statistics.pdf

20. Lawal N, Oche M, Isah B, et al. Knowledge, Attitude and Compliance with Safety Protective Measures and Devices among Commercial Motorcyclists in Sokoto Metropolis, Northwestern Nigeria. J Adv Med Pharm Sci 2018; 16(1): 1-9.

21. Michael GC, Aliyu I, Grema BA, et al. Knowledge of Zika virus disease among reproductive-age women attending a general outpatient clinic in Northern Nigeria. South African Fam Pract 2017; 59(4): 89-96.

22. Ndikom C. Substance Use and Perceived Consequences on Health and Safety among Commercial Motorcyclists in Ibadan North Local Government, Ibadan, Nigeria. Int J Trop Dis Heal 2014; 4(5): 555-67.

23. Bako IA, Atsaakaa HJ, Dane S. Perception and Use of Psychoactive Substances Among Commercial Motorcyclists in Makurdi Metropolis, Nigeria. J Res Med Dent Sci 2020; 8(3): 229-36.

24. Okebiro GN. Motorcycle (Boda-Boda) as Emerging Business for the Poor in Transport Industry and Sustainable Development in Modern Kenya. SSRN Electron J. Epub ahead of print 2016. DOI: 10.2139/ ssrn.2834204.

25. Joel M. Causes and consequences of commercial motorcycle incidents in Makurdi metropolis. Glob J Soc Sci 2013; 12(1)-11-8. 
26. Mohammed A. Identification of Risk Factors Involved in Road Incidents in Ghana. A Case Study of the Techiman Municipality. Kwame Nkrumah University of Science and Technology, 2013: 1-83. Available from : http://ir.knust.edu.gh/xmlui/handle/123456789/5757

27. Olumide AO, Owoaje ET. Young Age as a Predictor of Poor Road Safety Practices of Commercial Motorcyclists in Oyo State, Nigeria. Traffic Inj Prev 2015; 16(7): 691-7.

28. Adewoye KR, Aremu SK, Olomofe CO, Adeniyi AM, Agbana RD, Abioye OO, Issa YF. The prevalence and determinants of helmet use amongst commercial motorcyclists in Ido-Osi local government area. Arch Environ Occup Health. 2020;75(6):358-64.

29. Ohajinwa CM, Sangowawa AO, Omotade OO. Helmet-use and incidence of crash injuries among pillion passengers in Ibadan, Nigeria. Inj Prev 2010; 16(1): A237. Available from : https://injuryprevention. bmj.com/content/16/Suppl_1/A237.3.info

30. Mwakapasa EG. Attitude Towards And Practice Of Helmet Use Among Commercial Motorcyclists In Dar Es Salaam Region, Tanzania. Muhimbili University of Health and Allied Sciences, 2011: 18(1): A194. Available from : https://www.researchgate.net/ publication/275505538_Attitudes_towards_and_ practice_of_helmet_use_among_commercial_ motorcyclists_in_Dar_Es_Salaam_region_Tanzania

31. Matheka DM, Omar FA, Kipsaina C, et al. Road traffic injuries in Kenya: A survey of commercial motorcycle drivers. Pan Afr Med J 2015; 21:17. Available from : Matheka DM, Omar FA, Kipsaina C, et al. Road traffic injuries in Kenya: A survey of commercial motorcycle drivers. Pan Afr Med J 2015; 21: 1-9.

32. De Rome L, Ivers R, Fitzharris M, et al. Motorcycle protective clothing: Protection from injury or just the weather? Accid Anal Prev 2011; 43(6): 1893-1900.

33. McCartt AT, Blanar L, Teoh ER, et al. Overview of motorcycling in the United States: A national telephone survey. J Safety Res 2011; 42(3): 177-84.

34. Oluwadiya KS, Kolawole IK, Adegbehingbe OO, et al. Motorcycle crash characteristics in Nigeria: Implication for control. Accid Anal Prev 2009; 41(2): 294-8.

35. Nyachieo GMM. Socio-cultural and economic determinants of Boda-boda motorcycle transport safety in Kisumu county, Kenya. Hilos Tensados 2015; 1: 1-476. Available from : https://ir-library. ku.ac.ke/handle/123456789/14844.
36. Williams VH, Mclaughlin SB. A Survey of Motorcyclists Data for Research Design and Instrumentation. National Surface Transportation Safety Center for Excellence (NSTSCE). 2013: 1-159. Available from : https://vtechworks.lib.vt.edu/handle/10919/23317

37. Kolawole TG, Afolabi OJ. An Assessment of Motorcycle Operation in Ado-Odo Ota Local Government Area of Ogun State, Nigeria. Sci Technol Public Policy 2017; 18(1): 41-46.

38. Emiogun F, Faduyile F, Soyemi S, et al. Motorcycle incident mortality in Lagos, Nigeria: Impact of a traffic law. African J Trauma 2016; 5(2): 43. Available from : https://www.researchgate.net/ publication/319010004_Motorcycle_accident_ mortality_in_Lagos_Nigeria_Impact_of_a_traffic_law

39. Nathaniel D, S OA, S OO. Commercial Motorcycling Operations , Public Health and Safety Issues in Ibadan Metropolis. 2019;7(2): 7-13.

41. Olubomehin OO. The Development and Impact of Motorcycles as Means of Commercial Transportation in Nigeria. Res Humanit Soc Sci 2012; 2(6): 231-9.

42. Udeogu CU. The informal sector and employment generation in nigeria: a focus on okada transport business in nsukka metropolis by. University of Nigeria, Nsukka, 2016: 1-166. Available from : https:// mpra.ub.uni-muenchen.de/55538/

43. Owoaje E, Amoran O, Osemeikhain O, et al. Incidence of road traffic incidents and pattern of injury among commercial motorcyclists in a rural community in south western Nigeria. J Community Med Prim Heal Care; 2005. 17: 7-12.

44. Ndwiga SM, Mbakaya C, Kiiyukia C. Factors associated with road traffic incidents involving motorcyclists in Mwea Town, Kirinyaga County, Kenya. Afr J Health Sci 2019; 32(1): 59-73.

45. Sanusi AA, Emmelin M. Commercial motorcycle drivers' perceptions of risk and road safety in urban Nigeria: an explorative study. Int J Inj Contr Saf Promot 2015; 22(4): 328-39.

46. Olusayo Al, Oyetunde OB, Sundayadedokun O, et al. Risky behaviours among commercial motorcycle riders in Ogbomoso, Nigeria . Int J Adv Res 2015; 3: 506-11.

47. Jindal A, Mukherji S. World report on road traffic injury prevention. Med J Armed Forces India 2005; 61(1): 91. Available from : https://www.ncbi.nlm.nih. gov/pmc/articles/PMC4923400/ 